\title{
Kisspeptin: new biomarker of pregnancy
}

\author{
Priyanka Meena ${ }^{1}$, Rati Mathur ${ }^{1}$, Mohan L. Meena ${ }^{2 *}$
}

${ }^{1}$ Department of Biochemistry, SMS Medical College and Attached Hospital, Jaipur, Rajasthan, India
${ }^{2}$ Department of Obstetrics and Gynecology, SMS Medical College and Attached Hospital, Jaipur, Rajasthan, India

Received: 30 May 2019

Accepted: 26 June 2019

*Correspondence:

Dr. Mohan L. Meena,

E-mail:drmohanmeena@gmail.com

Copyright: () the author(s), publisher and licensee Medip Academy. This is an open-access article distributed under the terms of the Creative Commons Attribution Non-Commercial License, which permits unrestricted non-commercial use, distribution, and reproduction in any medium, provided the original work is properly cited.

\section{ABSTRACT}

Background: The recently identified hormone kisspeptin has been suggested to play an important regulatory role in placentation. The aim and objective of the study is the measurement of serum kisspeptin level in asymptomatic pregnant women and to find out the association of serum kisspeptin with gestational age in women with early pregnancy.

Methods: This was a longitudinal study to the evaluation of 178 asymptomatic pregnant women with a gestation of 6 to 16 weeks attending routine antenatal booking visit recruited as study participants from the Antenatal Clinical of Obstetrics and Gynaecology Department, S.M.S. Medical College and Attached Hospitals, Jaipur, Rajasthan, India.

Results: After initial clinical examination of every participant, a single blood sample was taken for the measurement of serum kisspeptin. Serum kisspeptin measurement test was performed by ELISA method and results were expressed as $\mathrm{ng} / \mathrm{ml}$. Pregnancy outcome was recorded prospectively. Mean serum kisspeptin level of study participants was $2.80 \pm 1.87 \mathrm{ng} / \mathrm{ml}$ and median were 2.41 (Range $0.244-14.06 \mathrm{ng} / \mathrm{ml}$ ). Our result showed the relationship of serum kisspeptin with gestational age $(\mathrm{GA})(\mathrm{p}<0.000)$.

Conclusions: serum kisspeptin level increases in pregnancy and showed positive relationship with gestational age significantly $(\mathrm{p}<0.000)$.

Keywords: Asymptomatic pregnant, Early pregnancy, Gestational age, Hormone, Kisspeptin

\section{INTRODUCTION}

Kisspeptin consists of a group of arginine -phenylalanine (RF) amide peptides encoded by the KISS1 gene, which binds to the kisspeptin receptor. ${ }^{1,2}$ Kisspeptin was first discovered in 1996 as a metastasis inhibitor in melanoma cell lines. ${ }^{1}$ In humans, the KISS 1 gene that encodes kisspeptin is located on the long (q) arm of chromosome 1 at $\mathrm{q} 32 .{ }^{3}$ Initially, this gene encodes an intermediate 145-amino-acid prepropeptide, which is unstable and biologically inactive. The prepropeptide is then cleaved into four biologically active peptides distinguished by their number of amino acids: kisspeptin-10, 13, 14 and 54
(52 in rodent animals). All kisspeptins contain the RFamide motif that can bind and activate KISS1R. ${ }^{4,5}$ The most abundant kisspeptin in the human circulation is kisspeptin-54. ${ }^{6}$ KISS1R belongs to the G-protein-coupled receptor family that was first identified as an orphan receptor in the rat brain. ${ }^{7}$ Kisspeptin is expressed most abundantly in the syncytiotrophoblast cells of the placenta, in which it may regulate invasion into the maternal uterine wall. ${ }^{8,9}$ Kisspeptin is also expressed in certain areas of the brain such as hypothalamus, amygdala, and caudate nucleus in addition to the pituitary, pancreas, adipose, testis, lymphocytes, and spleen. ${ }^{10}$ Because kisspeptin is produced by trophoblasts 
and trophoblast invasion is underway 5 days after blastocyst transplantation, plasma kisspeptin concentrations during the implantation period may reflect early developmental events associated with pregnancy outcome. ${ }^{11}$ It should be noted that the expression of KISS1 in the placenta or plasma kisspeptin levels may be affected by the adverse uterine environment. ${ }^{12,13}$ Plasma or serum kisspeptin levels are significantly increased in early pregnancy compared to non-pregnant controls. ${ }^{13-15}$

\section{METHODS}

The present study was conducted in the Department of Biochemistry, in association with the Department of Obsetetrics and Gynaecology, S.M.S. Medical College and Hospital, Jaipur, Rajasthan, India. A total of 178 asymptomatic pregnant women with a gestation age of 6 to 16 weeks attending routine antenatal booking visit, between June 2017 to November 2018, recruited as study participants. After taking written informed consent, a single blood sample was taken for the measurement of serum kisspeptin. Blood sample was collected in plane Vial .The serum was separated from the clotted specimen by centrifugation at $1300-1800 \mathrm{rpm}$ for 10 minutes within 2 hours. Serum was stored at $-20{ }^{\circ} \mathrm{C}$ in aliquots for analysis and Kisspeptin was measured by ELISA method using the following kit used as per manufacturers' instructions KISS1 (Fine Test, Wuhan Fine Biological Technology Co., Ltd.). Emergency admissions, cases of suspected miscarriage and women with renal failure were excluded. The protocol was approved by the institutional Ethics Committee. All pregnancies were dated according to an ultrasound scan performed in the antenatal clinic. Measurement of serum kisspeptin was performed using the Mindray MR-96 ELISA microplate reader and result were expressed as $\mathrm{ng} / \mathrm{ml}$. Range: 0.156-10 ng/ml; Sensitivity: $<0.094 \mathrm{ng} / \mathrm{ml}$.

\section{Statistical analysis}

Data were analyzed with the SPSS software version 23.0 trial version for Windows (SPSS Inc., Chicago, IL, USA). Data are presented as Mean \pm SD. The difference in would be analyzed using ANOVA test.

\section{RESULTS}

The study comprised a total of 178 asymptomatic pregnant women as study participants.

Table 1: Characteristics of study participants.

\begin{tabular}{|c|c|c|c|c|c|c|}
\hline \multirow{2}{*}{ Variables } & \multirow{2}{*}{ Mean \pm SD } & \multirow{2}{*}{ Median } & \multirow{2}{*}{ Range } & \multicolumn{3}{|c|}{ Percentiles } \\
\hline & & & & 25 & 50 & 75 \\
\hline Age (years.) & $24.90 \pm 3.70$ & 25.00 & $19-40$ & 22.00 & 25.00 & 27.00 \\
\hline GA (days) & $71.72 \pm 18.92$ & 70.00 & $41-110$ & 56.50 & 70.00 & 89.50 \\
\hline GA (weeks) & $10.23 \pm 2.70$ & 10.07 & $6-16$ & 8.11 & 10.07 & 12.71 \\
\hline Weight (kg) & $56.24 \pm 7.92$ & 56.00 & $40-78$ & 50.00 & 56.00 & 60.00 \\
\hline Height (cm) & $156.12 \pm 4.90$ & 156.00 & $146-170$ & 152.00 & 156.00 & 160.00 \\
\hline BMI & $23.71 \pm 3.34$ & 23.61 & $16.87-32.89$ & 21.08 & 23.61 & 25.30 \\
\hline SBP $(\mathrm{mmHg})$ & $114.85 \pm 5.96$ & 110.00 & $90-130$ & 110.00 & 110.00 & 120.00 \\
\hline DBP $(\mathrm{mmHg})$ & $74.10 \pm 5.43$ & 70.00 & $60-80$ & 70.00 & 70.00 & 80.00 \\
\hline
\end{tabular}

Table 2: Serum Kisspeptin level with gestational age in participants.

\begin{tabular}{|llll|}
\hline GA & N & Kisspeptin & \\
\hline$<8$ & 43 & Mean & SD \\
\hline 8 to 8.99 & 29 & 1.88 & 1.14 \\
\hline 9 to 9.99 & 15 & 2.39 & 1.16 \\
\hline 10 to 10.99 & 15 & 2.69 & 1.88 \\
\hline 11 to11.99 & 17 & 2.76 & 1.26 \\
\hline 12 to 12.99 & 18 & 2.97 & 1.27 \\
\hline 13 to 13.99 & 26 & 3.07 & 2.21 \\
\hline 14 to 14.99 & 10 & 3.68 & 2.95 \\
\hline$\geq 15$ & 5 & 4.05 & 2.47 \\
\hline Total & 178 & 4.79 & 1.60 \\
\hline
\end{tabular}

In Table 1 the mean maternal age, gestational age (GA) in days, GA in weeks, weight, height, body mass index
(BMI), systolic blood pressure (SBP) and diastolic blood pressure (DBP) of study participants 24.90 \pm 3.70 , 
$71.72 \pm 18.92, \quad 10.23 \pm 2.70, \quad 56.24 \pm 7.92, \quad 156.12 \pm 4.90$, $23.71 \pm 3.34,114.85 \pm 5.96$ and $74.10 \pm 5.43$ respectively. In our study mean level of serum kisspeptin level of study participants was $2.80 \pm 1.87 \mathrm{ng} / \mathrm{ml}$ and median were 2.41 (Range 0.244-14.06ng/ml), (data not shown in Table). Table 2 showed the relationship of serum kisspeptin with GA that were at $<8$ weeks $(1.88 \pm 1.14), 8-8.99$ weeks
(2.39 \pm 1.16$), 9-9.99$ week $(2.69 \pm 1.88), 10-10.99$ weeks $(2.76 \pm 1.26), \quad 11-11.99$ weeks $(2.97 \pm 1.27), \quad 12-12.99$ weeks $(3.07 \pm 2.21), 13-13.99$ weeks $(3.68 \pm 2.95)$, 1414.99 weeks $4.05 \pm 2.47)$ and $>15$ weeks $(4.79 \pm 1.60)$. By ANOVA test (Table 3) result was found to be highly significant $(\mathrm{p}<0.000)$.

Table 3: ANOVA for serum kisspeptin level with gestational age in participants.

\begin{tabular}{|llllllll|}
\hline & & & Sum of squares & Df & Mean square & F & Sig. \\
\hline \multirow{3}{*}{ Kis* GA } & Between groups & (Combined) & 98.776 & 8 & 12.347 & 4.032 & 0.000 \\
\cline { 2 - 7 } & Within groups & & 517.542 & 169 & 3.062 & & \\
\cline { 2 - 7 } & Total & & $\mathbf{6 1 6 . 3 1 8}$ & $\mathbf{1 7 7}$ & & & \\
\hline
\end{tabular}

\section{DISCUSSION}

The present study was undertaken to measurement of kisspeptin in pregnant women and to find out the correlation between serum kisspeptin level and gestational age in pregnant women. Horikoshi et al, studied that the circulating kisspeptin levels were low in males and non-pregnant females $(<2 \mathrm{pmol} / \mathrm{l})$ but increase in pregnancy. ${ }^{14}$ In humans, the plasma concentration of kisspeptin increases dramatically in the pregnancy, with a 900-fold increase in the first trimester and further increases to over 7000-fold in the third trimester compared to the non-pregnant women. ${ }^{15}$ It is most likely that the increase in the total number of trophoblast cells throughout the course of gestation is responsible for the dramatic increase in serum kisspeptin levels. ${ }^{16}$ Kisspeptin are mainly derived from placenta, the levels of plasma or serum kisspeptin can probably act as a biomarker for the function of the placenta and therefore viability of pregnancy. ${ }^{17-19}$ Dhillo et al, showed that Circulating kisspeptin levels fell again 5 days post-delivery to comparable concentrations prior to pregnancy, implicating a placental source. ${ }^{20}$ In support of a placental origin, plasma kisspeptin levels are increased in patients with gestational trophoblastic neoplasia and fall during and after treatment with chemotherapy. C. N. Jayasena, et al, revealed that the slope coefficient for correlation of kisspeptin levels with the time of gestation across the cohort of women who experienced miscarriage was significantly lower than for those who had an unaffected pregnancy suggests that a higher rate of increase in circulating plasma kisspeptin would be expected in a viable as compared with a failing pregnancy. ${ }^{15}$ Plasma kisspeptin significantly correlated with gestation ( $p$ value $<0.0001)$.

Together, these results suggest that kisspeptin may be marker of the establishment of early pregnancy. Our study evaluated the serum kisspeptin in 178 asymptomatic pregnant women. We showed that kisspeptin level associated with gestational age significantly ( $\mathrm{p}$ value $<0.000$ ) serum kisspeptin level would continue to increase throughout gestation unlike HCG, does not plateau. It shows that kisspeptin may be responsible for establishment of early pregnancy and after that maintaining the pregnancy. Therefore, these results suggest that kisspeptin may be marker of pregnancy in future. Kisspeptin may improve diagnostic accuracy in clinical setting. Limitation of our study was including 6 to 16 weeks only as a study participants.

\section{CONCLUSION}

This study demonstrated that kisspeptin is detectable in serum in early pregnancy and increases with gestation throughout pregnancy. Kisspeptin may have clinical utility in developing an accurate test of early pregnancy outcome in the future. Future studies are needed to validate these findings and assess the applicability of the serum kisspeptin assay in pregnancy outcome.

Funding: No funding sources

Conflict of interest: None declared

Ethical approval: The study was approved by the Institutional Ethics Committee

\section{REFERENCES}

1. Ohtaki T, Shintani Y, Honda S. Metastasis suppressor gene KiSS-1 encodes peptide ligand of a G-protein-coupled receptor. Nature. 2001;411(6837):613-7.

2. Muir AI, Chamberlain L, Elshourbagy NA. AXOR12, a novel human $G$ protein-coupled receptor, activated by the peptide KiSS-1. J Biol Chem. 2001;276(31):28969-75.

3. West A, Vojta PJ, Welch DR, Weissman BE. Chromosome localization and genomic structure of the KiSS-1 metastasis suppressor gene (KISS1). Genomics. 1998;54(1):145-8.

4. Pinilla L, Aguilar E, Dieguez C, Millar RP, TenaSempere M. Kisspeptins and reproduction: physiological roles and regulatory mechanisms. Physiol Rev. 2012;92(3):1235-316. 
5. $\mathrm{Hu} \mathrm{KL}$, Zhao $\mathrm{H}$, Chang $\mathrm{HM}$, Yu Y, Qiao J. Kisspeptin/Kisspeptin receptor system in the ovary. Front Endocrinol (Lausanne). 2017;8:365.

6. Lee YR, Tsunekawa K, Moon MJ, Um HN, Hwang J. Molecular evolution of multiple forms of kisspeptins and GPR54 receptors in vertebrates. Endocrinology. 2009;150(6):2837-46.

7. Lee DK, Nguyen T, O’Neill GP, Cheng R, Liu Y, Howard $\mathrm{AD}$, et al. Discovery of a receptor related to the galanin receptors. FEBS Lett. 1999;446(1):103-7.

8. Bilban M, Ghaffari-Tabrizi N, Hintermann E. Kisspeptin-10, a KiSS-1/ metastin- derived decapeptide, is a physiological invasion inhibitor of primary human trophoblasts. J Cell Sci. 2004;117(8):1319-28.

9. Roseweir AK, Katz AA, Millar RP. Kisspeptin-10 inhibits cell migration in vitro via a receptor-GSK3 $\beta$ FAK feedback loop in HTR8SVneo cells. Placenta. 2012;33(5):408-15.

10. Kotani M, Detheux M, Vandenbogaerde A. The metastasis suppressor gene KiSS-1 encodes kisspeptins, the natural ligands of the orphan $G$ protein-coupled receptor GPR54. J Biol Chem. 2001;276(37):34631-6.

11. Norwitz ER, Schust DJ, Fisher SJ. Implantation and the survival of early pregnancy. N Engl J Med. 2001;345(19):1400-8.

12. Xu X, Chiung YM, Lu F, Qiu S, Ji M, Huo X. Associations of cadmium, bisphenol $A$ and polychlorinated biphenyl co-exposure in utero with placental gene expression and neonatal outcomes. Reprod Toxicol. 2015;52:62-70.

13. Sullivan-Pyke C, Haisenleder DJ, Senapati S, Nicolais O, Eisenberg E, Sammel MD, et al. Kisspeptin as a new serum biomarker to discriminate miscarriage from viable intrauterine pregnancy. Fertil Steril. 2018;109(1):137-41.e132.
14. Horikoshi Y, Matsumoto H, Takatsu Y, Ohtaki T, Kitada C, Usuki S, et al. Dramatic elevation of plasma metastin concentrations in human pregnancy: metastin as a novel placenta-derived hormone in humans. J Clin Endocrinol Metab. 2003;88(2):914-9.

15. Jayasena $\mathrm{CN}$, Abbara A, Izzi-Engbeaya A, Comninos AN. Reduced levels of plasma kisspeptin during the antenatal booking visit are associated with increased risk of miscarriage. J Clin Endocrinol Metab. 2014;99(12):E2652-E2660.

16. Babwah AV. Uterine and placental KISS1 regulate pregnancy: what we know and the challenges that lie ahead. Reproduction. 2015;150(4):R121-R128.

17. Savitz DA, Hertz-PicciottoI, Poole C, Olshan AF. Epidemiologic measures of the course and outcome of pregnancy. Epidemiol Rev. 2002;24:91-101.

18. Newbatt E, Beckles Z, Ullman R, Lumsden MA. Ectopic pregnancy and miscarriage: summary of NICE guidance. BMJ. 2012;345:e8136.

19. Pillai RN, Konje JC, Tincello DG, Potdar N. Role of serum biomarkers in the prediction of outcome in women with threatened miscarriage: a systematic review and diagnostic accuracy meta-analysis. Hum Reprod Update. 2016;22(2):228-39.

20. Dhillo WS, Savage P, Murphy KG, Chaudhri OB, Patterson M, Nijher GM, et al. Plasma kisspeptin is raised in patients with gestational trophoblastic neoplasia and falls during treatment. Am J Physiol Endocrinol Metabol. 2006;291(5):E878-E884.

Cite this article as: Priyanka M, Mathur R, Mohan LM. Kisspeptin: new biomarker of pregnancy. Int J Reprod Contracept Obstet Gynecol 2019;8:3021-4. 